\title{
BNIP3L wt Allele
}

National Cancer Institute

\section{Source}

National Cancer Institute. BNIP3L wt Allele. NCI Thesaurus. Code C49376.

Human BNIP3L wild-type allele is located in the vicinity of 8 p21 and is approximately 28 $\mathrm{kb}$ in length. This allele, which encodes BCL2/adenovirus E1B 19-kDa protein-interacting protein 3-like protein, plays a role in the promotion of apoptosis and may be involved in tumor suppression. 